\title{
"In a Language That Was Not His Own": On Aḥlām Mustaghānamī’s Dhākirat al-jasad and Its French Translation Mémoires de la chair
}

\author{
Elizabeth M. Holt
}

\begin{abstract}
This paper argues that Aḥlām Mustaghānamīs novel Dhäkirat al-jasad (Memories of the Flesh) enacts a break with Algeria's Francophone literary past, multiply staging its affiliation with the Arabic language. The novel positions itself as part of an Algerian linguistic drama that, once translated into French as Mémoires de la chair, is problematically obscured. The press reviews of the novel's French translation serve to reveal, furthermore, that a French readership's familiarity with the significant corpus of Francophone Algerian literature mutes the legibility of the Algerian linguistic drama that Mustaghānamî’s novel articulates in the Arabic original.
\end{abstract}

\section{Keywords}

Modern Arabic literature, Francophone literature, Algeria, France, Maghreb, novel, translation, post colonial studies

When Aḥlām Mustaghānamī won the prestigious Naguib Mahfouz Medal for Literature in 1998 from the American University in Cairo for her first novel Dhäkirat al-jasad, she enthusiastically welcomed the prize. In her acceptance speech, Mustaghānamī underscored the "moral support" such a prize provides to her fellow "Algerian writers writing in Arabic who confront unarmed the onslaughts of Francophony."1 Mustaghānamī stages this conflict between the Arabic writer and the Algerian legacy of francophonie throughout Dhäkirat aljasad. The novel relies on an Arabic readership that is able to parse the novel's investment in and intertextuality with the Arabic literary tradition. Not only is much of this obscured in any translation, but due to the historical endurance of the Francophone Algerian literary tradition, the translation of this novel into French as Mémoires de la chair significantly mutes the linguistic drama being staged.

${ }^{1}$ Ahlam Mosteghanemi, “To Colleagues of the Pen," Al-Ahram Weekly On-line no. 409 (24-30 December 1998). 
First published in 1993, Dhäkirat al-jasad has become one of the bestselling Arabic novels, with over 130,000 copies sold, selling out multiple printings each year since its appearance. ${ }^{2}$ It is the first novel in a trilogy, followed by Fawdāa al-ḥawāss (Chaos of the Senses, 1997) and Mustaghānamī's most recent novel, 'Äbir sarì (Passer by a Bed, 2002). Mustaghānamī is also the author of two volumes of Arabic poetry, 'Alā marfá' al-ayyām (Upon the Harbor of Days, 1973) and al-Kitäba fi laḩat 'urì (Writing at the Moment of Nakedness, 1976), and a volume of literary criticism written in French, Algérie: Femmes \& écritures (Algeria: Women \& Writings, 1985).

Dhäkirat al-jasad became the center of much attention in Arabic literary and cultural circles. As the novel is written in the first person from the perspective of its male protagonist Khālid and is the first to be written in Arabic by an Algerian woman, a debate ensued in the Arab press as to whether Mustaghānamī in fact wrote the novel. Some suggested that the book was the work of either the Syrian poet Nizār Qabbānī or the Iraqi poet Sa dì Yūsuf, while the literary critic Rajā al-Naqqāsh argues in his book-length study that the novel is based off the Syrian novelist Haydar Haydar's Walima li-a'shäb $a l-b a h r$ [Banquet for Seaweed], published in 1983. ${ }^{3}$ Critics writing in English approach the question of authorship somewhat differently. Ellen McLarney considers the accusation that a man wrote the novel to be "the worst ignominy that can befall a woman writer." She takes the accusation as a jumping-off point for her argument that "Dhäkirat al-jasad is hardly a blueprint for women's writing... instead, it is a criticism of the masculine perspective, an exposure of its weaknesses, inefficacy, and impotence," a theme McLarney notes Mustaghānamī addresses in her critical work. ${ }^{4}$ Muhsin al-Musawi treats the masculine perspective in the novel from another angle, arguing that "there is an intimate suggestion that the male protagonist is given this narrative space to bypass moral strictures which a woman writer cannot escape in her own voice."5 Elsewhere in this seminal study of postcolonial Arabic fiction alMusawi addresses himself to the national context of the novel and its concern

${ }^{2}$ Kim Jensen, "A Literature Born from Wounds," Al-Jadid: A Review of Arab Culture and Arts 8, no. 39 (Spring 2002); "Author Profile: Ahlam Mosteghenami," Magharebia: The News and Views of the Maghreb (13 January 2005).

${ }^{3}$ Rajā' al-Naqqāsh, Qisșat riwāyatayn: Dirāsa naqdiyya wa-fikriyya li-riwāyat Dhākirat aljasad wa-riwāyat Walīma li-a shāb al-baḥr (Cairo: Dār al-hilāl, 2001).

${ }^{4}$ Ellen McLarney, "Unlocking the Female in Aḥlām Mustaghānamī," Journal of Arabic Literature 33, no. 1 (Leiden: Brill, 2002), pp. 24, 43.

${ }^{5}$ Muhsin al-Musawi, The Post-colonial Arabic Novel: Debating Ambivalence (Leiden, NLD: Brill, 2003), p. 238. 
with "the Francophone legacy from which no postcolonial writer in North Africa claims absolute freedom." ${ }^{\prime 6}$ Aida A. Bamia likewise directs our attention to the significance of Mustaghānamīs decision to write in Arabic in the Algerian national context, reminding us of the "heated polemics on the linguistic choices of the writers in the early years of [Algerian] independence." In this essay, I take up Dhäkirat al-jasad's investment in overcoming the Francophone Algerian legacy through writing in Arabic, and ask what happens to the legibility of this linguistic drama when the novel enters the world of francophonie through translation.

Mustaghānamī directs the reader to the politics of writing in Arabic rather than French before the first chapter of Dhäkirat al-jasad even begins. On the dedication page, Mustaghānamī addresses her project to the memory of her father, himself an important figure in the Algerian fight for independence, and to Mālik Haddād, an Algerian author who Mustaghānamī identifies as a "martyr of the Arabic language," who abandoned writing in French only to never write again, for he "swore after Algeria's independence not to write in a language that was not his own." ${ }^{8}$ What is at stake in Mustaghānamîs choice to write in Arabic is brought further into relief in a piece in Egypt's Al-Ahram Weekly, when Ferial Ghazoul quotes the Egyptian critic 'Alī al-Rā'ì as saying, "Aḥlām Mustaghānamī is a writer who has banished the linguistic exile to which French colonialism pushed Algerian intellectuals." In 2002, Algeria’s first President Ahmed Ben Bella described Mustaghānamī as "an Algerian sun illuminating Arabic literature. With her [creative] production she has raised Algerian literature to a stature worthy of the history of our struggle. We take pride in her Arabic pen, our pride as Algerians in our Arabness." ${ }^{10}$ Mustaghānamī’s decision to write for an Arabic-reading audience is here read as crystallizing a sense of Algerian national coherence. As Ben Bella's statement suggests, Algeria's history of polylingualism is the topic of much national debate, regarding not only the status of French and written Arabic, but also that of colloquial

${ }^{6}$ Ibid., p. 235.

7 Aida A. Bamia, "Dhäkirat al-Jasad (The Body's Memory): A New Outlook on Old Themes," Research in African Literatures 28 (Fall 1997), p. 87.

8 Aḥlām Mustaghānamī, Dhākirat al-jasad (Beirut: Dār al-ādāb, 1993), p. 5. "shahīd al-lugha al-'arabiyya"; "aqsama ba da istiqlāl al-jazāir alla yaktub bi-lugha laysat lughatahu." All translations from Arabic and French are my own unless otherwise specified.

9 Ferial Ghazoul, "Memory and Desire," Al-Ahram Weekly On-line, no. 409 (24-30 December 1998).

${ }^{10}$ Cited on Mustaghānamīs Arabic website, www.mosteghanemi.net. Also in shortened form in French translation in "Le grand art de Ahlem Mosteghanemi," La Presse/All Africa (6 June 2005). 
Algerian Arabic, as well as regional languages such as Kabyle or Tamazight, and Touareg. ${ }^{11}$

Following the achievement of independence from French colonialism in 1962, Algeria pursued an active policy of Arabization, a difficult project in a linguistically diverse country in which French colonial educational policies had wrought staggeringly high illiteracy rates and left behind an intelligentsia whose language of scholarship was overwhelmingly French. In the fifties and early sixties, Algerian writers and intellectuals who were educated in Arabic had been students of the religious schools run by the 'ulamä' in Algeria, or had received university diplomas outside Algeria, in Tunis, Cairo, Damascus or Baghdad. ${ }^{12}$ Mustaghānamīs French-language study of the role and symbol of women in Algerian literature, written as part of her doctoral studies at the Sorbonne and entitled Algérie: Femmes \& écritures, identifies this generation of Arabic writers writing in Algeria as, "paradoxically... opt[ing] for a rather rigid conformity as much at the literary level as at the social and political." ${ }^{13}$ Mustaghānamī finds the conformity and conservativism of this group of writers

all the more surprising given that they intervened at a moment in which Arabization was keeping score and at a moment when the youth were following with particular attention the [Arabic] literary evolution [that was taking place] in the countries of the Mashreq. In all probability, it was in literature itself where the problem resided, and not with its public. ${ }^{14}$

In Mustaghānamī's estimation, it was not until the 1970s with the advent of writers such as 'Abd al-Ḥ̂mīd Bin Hadūqa and al-Ṭāhir Wațtāar that Arabic literature produced in Algeria began to contest the conformity and conservatism of the previous generation's Arabic-language writing. During the 1950s and 1960s, it was Algerian literature written in French, such as Kateb Yacine's seminal Nedjma ${ }^{15}$ (1956) and Rachid Boudjedra (Rashīd Abū Jadra)'s La

${ }^{11}$ For a detailed description of Algeria's linguistic multiplicity, see Reda Bensmaïa, "La littérature algérienne face à la langue: le théâtre de Kateb Yacine," Itinéraires et contacts de cultures 4-5 (Paris: Éditions L'Harmattan, 1984) 59-82. For an analysis of Algerian linguisitic debates at the end of the twentieth century, see Anne-Emmanuelle Berger, ed., Algeria in Others' Languages (Ithaca, NY: Cornell University Press, 2002). For a consideration of the Arabic novel in Algeria from 1972-88, see Debbie Cox, Politics, Language, and Gender in the Algerian Arabic Novel (Lewiston, NY: Edwin Mellen Press, 2002).

${ }_{12}$ Ahlem Mosteghanemi, Algérie: Femmes \& écritures (Paris: L’Harmattan, 1985), pp. 40-1.

13 Ibid., pp. 40-1.

${ }_{14}$ Ibid., pp. 41-2.

15 Kateb Yacine, Nedjma (Paris: Éditions du Seuil, 1956). 
répudiation ${ }^{16}$ (1969), that Mustaghānamī identifies as contesting the social, political and literary order in Algeria. ${ }^{17}$ Indeed, a character named Kateb Yacine appears in the pages of Dhäkirat al-jasad as Khälid's prisonmate during the struggle for Algerian independence, and the two meet again years later in Tunis. Khālid cites their shared time in prison as the moment when Kateb Yacine first conceived of writing Nedjma, during what Dhäkirat al-jasad describes as "the labor pains of bitterness and disappointment and great nationalist dreams." 18

Both Kateb Yacine and Rachid Boudjedra (Rashīd Abū Jadra) would go on, like Mālik Haddād, to renounce writing literature in French. Kateb Yacine turned to a Brechtian-style ephemeral traveling theatre combining colloquial Algerian Arabic, Kabyle/Tamazight (his maternal language), and French in fluid scripts open to improvisation and change over the course of a tour. This polylingual theater was, for Kateb Yacine, an answer to the question of how, as Reda Bensmaïa rhetorically put it, "to live in several languages and only write in one?" 19 Previous to his decision to move away from writing novels and into popular theater, however, Kateb Yacine had been an enormously influential French-language Algerian writer, best known for his novel Nedjma. Kateb Yacine's writing during this period worked not only on the French historical and cultural record, but on the French language as well. As Jacques Alessandra observes, in Kateb Yacine's interventions into French literature, "the French language is pulverized, atomized, laid bare, relieved of its conventional poise." 20

Boudjedra (Abū Jadra), for his part, left behind French as his language of literary expression in 1981 in order to take up writing in Arabic, though he has since returned to writing in French. His 1981 move from French to Arabic was prefigured by the sort of work his earlier writing in French did on the French language. In his first novel La répudiation, which was banned in Algeria because of its social critique, Boudjedra (Abū Jadra)'s use of grammar, particularly his occasional placement of the verb first in a phrase, as well as his longer sentence style, evoke an affinity with the Arabic language and its literature, as does the novel's intertextuality with texts such as $A$ Thousand and One Nights as well as authors such as al-Tawhịīi, Ibn Bațtūta, and Ibn al-'Arabī. ${ }^{21}$ In an interview with H. A. Bouraoui in Présence Francophone in

\footnotetext{
${ }^{16}$ Rachid Boudjedra, La répudiation (Paris: Denoël, 1969).

${ }_{17}$ Mosteghanemi 1985, p. 43.

${ }_{18}$ Mustaghānamī 1993, p. 325 "makhāẹ al-marāra wa-l-khayba wa-l-aḥlām al-wațaniyya al-kubrā."

19 See Bensmaïa, p. 64.

${ }^{20}$ Jacques Alessandra, "Pourquoi Kateb Yacine a-t-il abandonné l'écriture française?," Présence Francophone no. 24 (1982), p. 6.

${ }^{21}$ Roger Allen, "Translation Translated: Rashīd Abū Jadrah's Márakat al-zuqāq," Oriente Moderno 2-3 (1997), p. 166.
} 
1979, Boudjedra (Abū Jadra) is asked: "You have added a few words in Arabic into the body of the text... why this inclusion [of Arabic] in a novel written in French?" 22 Boudjedra (Abū Jadra)'s response tellingly replaces Bouraoui's "inclusion" with "intrusion":

the... question deals with the intrusion of Arabic. For me, it is a symbolic formulation. We try to write French in a certain way; the French that we write is not, I believe, that which a French writer would write. It is for that [reason] that we attempt to rid ourselves of the classical yoke, of conventionalism, to do those things that are particular to us. But at the same time, I use Arabic as a symbolic, because I believe that one day we will simply write in our mother tongue, without, because of that, losing French as a language for external use. ${ }^{23}$

When Boudjedra (Abū Jadra) did switch over to writing in Arabic, it would be French that did the intruding, with French text appearing in the middle of an Arabic paragraph and sometimes in the middle of an Arabic sentence in novels such as his $1986 \mathrm{Ma}$ rakat al-zuqa $q,{ }^{24}$ achieving a jarring orthographic effect that can be read as a commentary on Algeria's linguistic history.

Boudjedra (Abū Jadra) never left French behind, however. Even before returning to writing in French, as Roger Allen notes, Abū Jadra (Boudjedra)'s move to write in Arabic was concomitant with his participation in the translation of these Arabic-language novels into French..$^{25}$ Allen observes that the French rendering of Ma'rakat al-zuqāq as La prise de Gibraltar "is termed a translation by Antoine Moussali 'in collaboration with the author."' 26 Allen further points out that the novel itself, both in its Arabic and French versions, stages multiple acts of translation. Using the text's investment in translation as a point of departure, Allen explores how these two versions read against nineteenth- and twentieth-century Algerian history bring into "focus... the postcolonial condition and its placement in two different linguistic and cultural contexts." 27 Pascale Casanova, in The World Republic of Letters, discusses Boudjedra's (Abū Jadra) position between French and Arabic, noting that he is "a diagraphic author, since he operates continually between two languages, subject to the tension of translation, itself an essential element of his work." ${ }^{28}$

${ }^{22}$ H. A. Bouraoui, "Entretien avec Rachid Boudjedra," Présence Francophone no. 19 (1979), p. 164.

${ }^{23}$ Ibid., pp. 164-65.

${ }^{24}$ Rashīd Abū Jadra, Márakat al-zuqāq (Algiers: al-Mu’assasa al-wațaniyya li-l-kitāb, 1986).

25 Allen, p. 165.

26 Ibid.

${ }^{27}$ Ibid., p. 172.

${ }^{28}$ Pascale Casanova, The World Republic of Letters, trans. M. B. DeBevoise (Cambridge, MA: Harvard University Press, 2004), p. 267. 
The fraught role of language(s) in the Algerian national context probed in works by Algerian authors such as Mālik Haddād, Kateb Yacine, Rachid Boudjedra (Rashīd Abū Jadra), and more recently Aḥlām Mustaghānamī, resonates with Benedict Anderson's argument about national languages in his influential work Imagined Communities. Anderson points to the central role of print language(s) in consolidating the imagined community of the nation. He directs readers to the significance of "two forms of imagining which first flowered in Europe in the eighteenth century: the novel and the newspaper. For these forms provided the technical means for 're-presenting' the kind of imagined community that is the nation." ${ }^{29}$ Both the novel and the newspaper interpellate a public reading the same language and familiar with the same geography, surfacing the simultaneity of these common experiences. Indeed, Anderson describes the novel, with the multiple itineraries of its multiple characters echoing those of its many readers, as a "complex gloss upon the word "meanwhile," 30 fostered by the existence of "monoglot mass reading publics." ${ }^{31}$ As Anderson notes, many anticolonial and postcolonial nationalist leaders would come to consider language as one more in a list of "emblems of nation-ness, like flags, costumes, folk-dances, and the rest." ${ }^{32}$ The novel or newspaper in form helped enable the imagining of the national community: "there is a special kind of contemporaneous community which language alone suggests... The image: unisonance." 33

Writing in Arabic marks a break with French colonialism that for all their pulverizing of the French language, French-language writings such as Kateb Yacine's or Rachid Boudjedra (Abū Jadra)'s could not enact on an emblematic level. Arabic serves to connect Algeria as a nation with an Arab past, present and future. Dhäkirat al-jasad does manifest Algeria's entanglement with a history of Western and particularly French cultural production through reference to European and American authors, and the inclusion of an occasional line of French. Yet because it is written almost entirely in Arabic, the novel's "contemporaneous community" is clear from the outset. Claims that the novel was written by other poets of the Arabic language such as the Syrian poet Nizār Qabbānī or the Iraqi poet Sa'dī Yūsuf serve only to confirm the novel's linguistic and national orientations as being rooted in an Arab and Arabophone cultural context.

${ }^{29}$ Benedict Anderson, Imagined Communities: Reflections on the Origin and Spread of Nationalism (New York: Verso, 1983), pp. 24-5.

${ }^{30}$ Ibid., p. 25.

${ }^{31}$ Ibid., p. 43.

32 Ibid., p. 133.

33 Ibid., p. 145. 
There are moments in the text where the novel intertextually weaves itself into an Arabic literary tradition, as when the protagonist Khālid invites Aḥlām/ Hayāt out onto his "balcony" (shurfa). ${ }^{34}$ The word repeats twice more in the space of the next four lines, and then the novel briefly moves to the "tears" $($ dum $\bar{u})$ of the city, before repeating the word "rain" (matar) six times over the course of nine lines. ${ }^{35}$ Khālid then speaks of Hayāt/Ahlām's "eyes" ('aynāyki). ${ }^{36}$ An avid reader of modern Arabic poetry may be reminded of Badr Shākir al-Sayyāb's famous poem "Unshūdat al-mațar," and indeed Khālid recites the first two lines of the poem on the next page. ${ }^{37}$ The novel's foreshadowing of this poem's appearance through the repetition of a word like matar, which itself repeats over and over in the lines of the poem, interpellates and relies on an Arabic readership. Hilary Kilpatrick's recent treatment of the ațläl motif in Dhäkirat al-jasad further locates the novel as being in conversation with not only the contemporary Arabic literary heritage but also the classical and even pre-Islamic. ${ }^{38}$ Mustaghānamīs decision to include Algerian colloquial in the text while simultaneously making it accessible to Arabic readers unfamiliar with Algerian colloquial further elaborates the novel's concentric linguistic bearings.

In his classic of anticolonial French-language literature Portrait du Colonisé précédé du Portrait du Colonisateur, translated into English as The Colonizer and the Colonized, the Tunisian author Albert Memmi points out that the style of "colonial bilingualism" experienced in places such as the Maghreb "is neither a purely bilingual situation in which an indigenous tongue coexists with a purist's language (both belonging to the same world of feeling), nor a simple polyglot richness benefiting from an extra but relatively neuter alphabet; it is a linguistic drama." ${ }^{39}$ Memmi goes on to identify the "colonized artist" as "slightly ahead of the development of the collective consciousness in which he participates and which he hastens by participating in it. And the most urgent claim of a group about to revive is certainly the liberation and restoration of its language." ${ }^{40}$ Dhäkirat al-jasad's participation in the Algerian lin-

${ }_{34}$ Mustaghānamī 1993, p. 159.

35 Ibid., p. 160.

36 Ibid.

37 Ibid., p. 161.

${ }^{38}$ Hilary Kilpatrick, "Literary Creativity and the Cultural Heritage: The atläl in Modern Arabic Fiction," Tradition, Modernity, and Postmodernity in Arabic Literature: Essays in Honor of Professor Issa J. Boullata, Kamal Abdel-Malek and Wael Hallaq, eds. (Boston: Brill, 2000): pp. 39-43.

${ }^{39}$ Albert Memmi, Portrait du Colonisé précédé du Portrait du Colonisateur (Paris: Éditions Buchet/Chastel, Corrêa, 1957). All quotes from the English translation: Albert Memmi, The Colonizer and the Colonized, trans. Howard Greenfield (Boston: The Orion Press, 1965), pp. 107-8.

${ }^{40}$ Ibid., p. 110. 
guistic drama through the "liberation and restoration" of the Arabic language in the Algerian literary scene is signaled from the novel's dedication page, as the novel identifies with a younger, Arabic-educated generation sympathizing with the linguistic politics that led Mālik Haddād to die a martyr for the Arabic language. The novel, as Memmi's analysis of colonial linguistic dynamics helps to surface, is part of a linguistic drama in which the language of writing is anything but neutral. Arabic becomes an actor in this drama, taking as its adversary not only the French language, but the very idea that Algeria's linguistic experience of French colonialism was anything like "a simple polyglot richness."

It stands as a striking commentary on this linguistic drama that in the major French press reviews of the French translations of Mustaghānamīs novels, Mémoires de la chair ${ }^{41}$ (2002) and Le chaos des senses ${ }^{42}$ (2006), and in French mainstream press articles mentioning her work that have come out since 2002, there is a remarkable degree of silence on the language in which these novels were originally written. ${ }^{43}$ It is mentioned in only two of these reviews that the novels are translations, despite the different Albin Michel editions of Mémoires de la chair and Le chaos des senses prominently including on their covers and title pages that the novels are part of a series called "Les Grandes Traductions" (Great Translations). Rather, Mustaghānamī is frequently identified only by her nationality ${ }^{44}$ a common practice in the French press. Valérie Lotodé notes in a

${ }^{41}$ Ahlam Mosteghanemi, Mémoires de la chair, trans. Mohamed Mokeddem (Paris: Éditions Albin Michel, 2002).

${ }^{42}$ Ahlam Mosteghanemi, Le chaos des senses, trans. France Meyer (Paris: Éditions Albin Michel, 2006).

43 See "Publié et édité par la librairie Bibliopolis: livre lecture, le magazine du bibliophile sur les étals," La Tribune (9 February 2005); Isabelle Nataf, “"Vol de nuit' se pose à Alger," Le Figaro (4 March 2003); "Beyrouth, vitrine de l'édition française," Le Monde des Livres (15 November 2002); Duquesne Jacques, "Si je t'oublie Constantine," L'Express (31 October 2002); "Le Monde des Livres - Actualités de l'édition française - Dominique Mainard, lauréate du prix roman Fnac," Le Monde des Livres (6 September 2002); "Ahlam Mosteghanemi. Mémoires de la chair," Libération Livres (22 August 2002). Interestingly, there was an article in the French Communist paper L'Humanité the year before the publication of Mémoires de la chair that mentions Mustaghānamī as one of a number of "auteurs arabes" whose work the Avicenne bookstore is increasingly adding to its collection. French, like Arabic, does not distinguish as English does between Arab and Arabic, and so a certain ambiguity remains. Here too Mustaghānamī is identified as Algerian. However, the article is also concerned with practicalities of translation. See Sadek Aïssat, "Un Océan perdu: La littérature arabe vue par Hachim Mouawiyeh, directeur de la librairie Avicenne à Paris, l'une des plus importantes d'Europe," L'Humanité (29 November 2001).

${ }^{44}$ See "Publié et édité par la librairie Bibliopolis: livre lecture, le magazine du bibliophile sur les étals," La Tribune (9 February 2005); "Beyrouth, vitrine de l'édition française," Le Monde des Livres (15 November 2002); Duquesne Jacques, "Si je t'oublie Constantine," L'Express (31 October 2002). 
recent issue of Présence Francophone: "the literary critic... the press and the media generally circumscribe French-language authors into their precise geographical and cultural areas." ${ }^{\text {"5 }}$ Lotodé explores how the French reception of Kateb Yacine and Rachid Boudjedra (Abū Jadra) construct them as "authentic Algerian" authors.

Central to identifying an author as "authentically Algerian," according to Lotodé, is a symbolic vocabulary that figures the woman and particularly the mother as representative of Algeria. While Mustaghānamī's novel Dhäkirat al-jasad arguably works to undermine the efficacy or relevance of this symbolic figuring of the Algerian woman, the novel's engagement with this trope nevertheless makes the French translation appear as part of a recognizable and Francophone Algerian literary tradition. The novel's setting in both Paris and Constantine may solidify this affinity, for, as Lotodé explores in her article, part of being an "authentically Algerian" author means taking Algeria as a setting and context for writing. That Mustaghānamī can be read by a French audience as "authentically Algerian" without reference to language further underscores the French press's relative disregard for the participation of Mustaghānamīs recent novels in a linguistic drama that is so pressingly part of Algerian decolonization.

The French press's disregard for the novel's original language echoes the French translation's treatment of the portion of the Arabic dedication page addressed to Mālik Haddād. It reads:
A Malek Haddad
L'enfant de Constantine qui fit le serment après l'indépendence de ne pas écrire dans une langue qui n'était pas la sienne... il est mort de son silence
(To Mālik Haddād
The child of Constantine who took the oath after independence to not write in a language that was not his own... he died of his silence)

The French omits that it is after the independence of Algeria that Haddād took this oath to never write again in a language not his own, thereby obscuring the imperial, national and historical contexts in which this work is to be situated. The French translation goes still further, however, omitting entirely

45 Valérie Lotodé, "Le rôle de la critique dans la réception de l'oeuvre romanesque de Rachid Boudjedra," Présence Francophone no. 61 (2003), p. 131. 
the portion of the dedication regarding Haddād becoming a "martyr of the Arabic language," the first writer to decide to die silent and longing for Arabic. The only reference to Arabic in the French translation of the dedication comes in the portion addressed to Mustaghānamīs late father, when Mustaghānamī wills that her father might find someone "there" who can read in Arabic so that they might read his novel to him. Any worldly references to the painful linguistic history of Algeria in which the Arabic of Dhäkirat aljasad is so invested are thus effaced from the framing dedication page of the French translation.

With the linguistic specifics of Mālik Haddād's decision to abandon writing "in a language that was not his own" thus obscured from the dedication page, the burden of decrypting the linguistic drama being staged with the inclusion of several lines of Haddād's writing in the body of the French translation thus falls upon the reader and her knowledge of Haddād's career. In the Arabic original, however, the reader knows from the dedication page that Haddād never wrote in Arabic, and that his martyrdom to Arabic has something to do with the independence of Algeria. When lines of Haddād's writing appear in the Arabic text in Arabic, Mustaghānamī is legibly enacting a sort of postmortem linguistic liberation for Haddād's words before the novel's Arabic readership. She is also marking that while her father and many in his generation of Algerians were illiterate, and while Haddād could only write in French or stay silent despite his longing to write in Arabic, Mustaghānamì is part of a generation that can redress some of the linguistic sacrifices imposed on her forebears. Unlike a novelist such as Rashīd Abū Jadra (Boudjedra) who, as Allen and Casanova point out, is deeply invested in moving back and forth between Arabic and French, Mustaghānamī, in writing Dhäkirat aljasad, enacts a literary break with this sort of linguistic métissage through the novel's focus on writing and living in Arabic. The decision by the protagonist Khălid to move from France back to Algeria at the end of the novel plays out in a geographical register this literary-linguistic shift.

Unlike Abū Jadra (Boudjedra) who announces his central role in the translation of his works between Arabic and French, Mustaghānamī is nowhere noted as participating in the French translation of her novel as Mémoires de la chair. Mustaghānamī privileges Arabic in Dhäkirat al-jasad, yet like Abū Jadra in his Arabic writings she includes the occasional intrusion of French. As Casanova notes of "authors on the periphery [of the world republic of letters]":

The strategies of such authors... can therefore be described as sorts of very complex equations, containing two, three, or four unknowns, that take into account simultaneously the literariness of their own language, their political situation, 
their degree of involvement in a national struggle, their determination to achieve recognition in the literary centers, the ethnocentrism and blindness of these same centers, and the necessity of making them aware of the difference of authors on the periphery. ${ }^{46}$

Dhäkirat al-jasad's literary-linguistic focus on Arabic and the Algerian national condition works out a considerably different equation than Abū Jadra (Boudjedra)'s works, with significant implications for the novel's translation, particularly into French, the other major literary language in the Algerian linguistic drama. For instance, the intrusion of French in the pages of the Arabic original of Dhäkirat al-jasad is lost in the French translation, for it is impossible for the French translation to mark the orthographic alterity of these French lines in the original Arabic text. The novel's discussion of both French and Arabic literary and cultural references and experiences, once in French translation, serves to further occlude the intrusive status of actual lines of French in the Arabic original. In the Arabic original, Khălid, the novel's first-person narrator, recounts his first meeting after many years with Aḥlām/Hayāat, to whom much of the novel is addressed. They are at the opening of Khālid's painting exhibit, and before speaking to Hayāt/Aḥlām, Khālid thinks to himself in Arabic, "Is it reasonable after twenty years to greet you and ask you in a neutral French." ${ }^{77}$ The French translation of this portion reads: "What madness! To see you again twenty years later, to greet you in French." ${ }^{48}$ While both passages register that the next line of the novel is to be understood as 'being said' in French, the Arabic does so in Arabic, while the French does so in French. The orthographic shift that occurs next in the Arabic is thus lost in the French. In the Arabic text, Khālid asks in French written in French: "And how are you, Miss?" 49 The next line in the Arabic text reads, in Arabic: "And you responded to me with the same linguistic distance," followed by Ahlām/Hayāt's response in French written in French: "Fine, thank you." W0 What Mémoires de la chair cannot translate is precisely this linguistic distance, for it is orthographically, historically, dramatically not the same. The French translation can only point its readers to a vague linguistic distance that its readers must imagine. The Arabic original, on the other hand, orthographically shows the distance, and it

\footnotetext{
46 Casanova, p. 259.

${ }^{47}$ Mustaghānamī 1993, p. 66 "A-ya'qil ba da 'ashrīn sanna an uṣâfahaki wa as'alaki bi-lugha faransiyya muhāyida."

${ }^{48}$ Mosteghanemi (trans.) 2002, p. 55 "De la folie! Te revoir vingt ans après, te saluer en français."

49 Mustaghānamī 1993, p. 66 "Mais comment allez vous mademoiselle?"

${ }^{50}$ Ibid. "fataruddinna 'alayya bi-nafs al-masāfa al-lughawiyya"; "Bien... je vous remercie."
} 
is one that can be apprehended by Arabic readers whether or not they speak French: the very jarringness of two Algerians speaking in French in the middle of an Arabic novel marks the distance.

When Khālid discovers that Hayāt/Aḥlām writes stories and novels in Arabic, she explains to him that, "it was possible for me to write in French, but Arabic is the language of my heart." ${ }^{51}$ Here, the reader of the French translation is asked to imagine a linguistic situation that is contrary to what the French translation is able to perform. The decision that Ahlām/Hayāt and Khălid only speak in Arabic from this disclosure forward reads in the Arabic original as a resolution of a linguistic tension in the text, a tension represented to the Arabic reader both by the intrusion of lines of French into the text, as well as by the counterfactual reading that the Arabic demanded when the majority of this conversation 'in French' appeared in the text in Arabic. From this point forward in the Arabic, speaking in French (or 'in French') becomes a sort of betrayal of a linguistic contract or a measure of distance from the contemporary situation of the majority of Algerians. For the French reader, however, the decision to speak only in Arabic, as well as Hayāt/Aḥlām's pronouncement that "Arabic is the language of my heart," are rendered equivocal merely by appearing in French translation.

The passages of the novel containing colloquial Algerian Arabic likewise indicate that the linguistic distances being measured in the Arabic original do not translate into the French. While short conversations take place in the Arabic in Algerian dialect, the French translation only contains the occasional, italicized transliteration of a word or two, such as "Wachek?" or "Ä̈chac." 52 Lost then is not only the intimacy colloquial Arabic carries in the text, but also the distance between colloquial and standard, written Arabic, itself a major issue in Algerian (and other Arab) linguistic debates. Many novels written in French engaging Algerian issues include the occasional word or phrase of transliterated colloquial Arabic. The difference being represented in the Arabic text between Arabic registers becomes in the French text at most a sign that the novel is "authentically Algerian." The untranslatability of colloquial Arabic problematizes Richard Jacquemond's compelling suggestion-as-question:

How can the translator avoid the complementary temptations of exoticizing and naturalizing the Arabic text, while he is pressed to do so by the publisher? Should he recycle the narrative strategies of Arab-Francophone writers as a means to assert and preserve the Arabic text's difference? ${ }^{33}$

${ }^{51}$ Mustaghānamī 1993, p. 91 "kāna yumkin an aktuba bi-l-faransiyya, wa lakin al-'arabiyya hiya lughat qalbī”

52 Mosteghanemi (trans.) 2002, pp. 55, 73.

53 Richard Jacquemond, "Translation and Cultural Hegemony: The Case of French-Arabic 
As seen above, recycling the narrative strategies used by Arab-Francophone authors writing in French, in the translation of Arabic into French, serves only to register that the novel is, in this case, "authentically Algerian." Such a translation into French would further require that the translator impose something like the "atomizing, pulverizing" style of Kateb Yacine or Rachid Boudjedra (Rashìd Abū Jadra)'s French writing onto the novel in order to mark its "difference," but this difference would be that between mainstream French and French from a decolonizing Algerian perspective. It would not measure the linguistic distance between Arabic and French from a decolonizing Algerian perspective. The contexts cannot be made commensurate; the distances being measured are not the same.

An opportunity to preserve some of the "Arabic text's difference" is lost when the French translation of Dhäkirat al-jasad deletes a portion of the text that spells out in Arabic letters the name that Khālid carried to the novel's female addressee in Tunisia from her father clandestinely fighting in the Algerian resistance. As a newborn in her father's absence, her mother named her Hayāt, a name that means life. Khālid delivered the name her father wished her to have-Aḥlām, a name that means dreams or utopia as well as insightswhich he then registered as her official name. This name is never explicitly stated in the Arabic, but rather is spelled out. In lieu of translating this portion of the Arabic, the French moves down a few lines the translated phrase, "I cling to the letters of your name." ${ }^{44}$ Because the French does not translate the passage that comes next in the Arabic, the French reader understands this comment as referring to the mother-given name Hayāt, the only name given for the novel's female addressee in the French translation. Indeed, the female addressee's father-given name is only alluded to in the French translation as that which the protagonist does not say, as when Khālid muses over what name to use when he speaks of her:

Et quand je te nomme, de quel nom dois-je user? Celui décidé par ton père et que j'ai moi-même fait inscrire à l'état civil à sa place ou bien le premier, celui que tu avais porté six mois? Hayat! La vie!... C'est le nom sous lequel je t'ai connue, que je suis seul à connaître, qui ne court sur aucune langue, n'est mentionné par aucun livre, ni revue, ni registre officiel... Ce nom que j'ai moi-même étouffé un jour en te donnant de la légalité d'un autre. ${ }^{55}$

\footnotetext{
Translation," Rethinking Translation: Discourse, Subjectivity, Ideology, Lawrence Venuti, ed. (London: Routledge, 1992), p. 154.

${ }^{54}$ Mosteghanemi (trans.) 2002, p. 33 "je m'accrochai aux lettres de ton nom."

55 Ibid., p. 36.
} 
(And when I name you, what name should I use? The one decided on by your father and that I myself entered in the civil registry in his place, or the first, the one that you carried for six months? Hayāt! Life!... It is the name under which I met you, and that I alone know, that never rolled off a single tongue, is not mentioned in any book, magazine or official register. That name that I myself snuffed out one day in giving you the legality of another.)

Missing in the French translation is the national-linguistic context in which the Arabic original locates this act of naming that snuffed out the name Hayāt. The Arabic passage that is not translated into French deconstructs the fathergiven name Ahlām into Arabic letters and sounds which it then connects up with Arabic words. What makes this passage in the novel, and the similar ones that follow, so difficult to translate is precisely Mustaghānamīs investment in writing literature in Arabic. Here she embroiders Arabic letters and sounds into the fabric of the narrative, such that the letters and sounds of the name Ahlām are intertwined with the Algerian war for independence:

$$
\begin{aligned}
& \text { بين ألف الألم وميم المتعة كان اسمك. }
\end{aligned}
$$

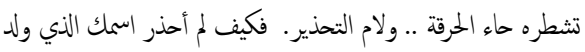

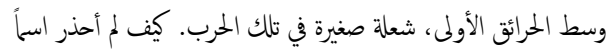

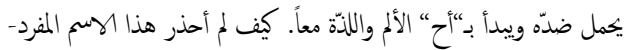

$$
\begin{aligned}
& \text { الجمع كاسم هذا الوطن، وأدرك منذ البدء أنّ الجمع خلق دائماً ليقتسم! }
\end{aligned}
$$

(Between the alif of alam (pain) and the mim of mut $a$ (pleasure) was your name. The ha' of hurqa (burning; also agony) bisects it [your name]... as does the läm of caution. For how can I not be cautious of your name that was born amidst the first fires ( $\operatorname{ara} \vec{a} i q)$, a small flame in this war. How can I not be cautious of a name that carries its opposite and begins with the "aḥ" of pain (alam) and delight together. How can I not be cautious of this solitary name-plural like the name of this nation (watan), when I realized from the beginning that the plural is always created in order to be divided.)

This passage in the Arabic engages not only Arabic letters, sounds, words and grammar, but also links them up with Algeria's national war of liberation. The caution with which the protagonist meets Ahlām's name is here connected to the fires of war, while the fact that the name is a broken plural in Arabic is likened to the Arabic name of the nation in question: al-Jazä ir. Deciphering this passage of the novel when rendered into the sort of translation I have attempted above requires that its reader have some familiarity with Arabic

${ }^{56}$ Mustaghānamī 1993, p. 37. 
grammar in order to access, for instance, the grammatical connection being made between the name Ahlām and the name of the nation, al-Jazä ir. Had this passage been included in the French translation, it might have afforded its readers the possibility of accessing just the sort of difference Jacquemond calls upon translators to preserve. However, this omission stands as a poignant commentary on the failure to carry the linguistic investitures of Dhäkirat aljasad into French.

Later in the text, Ahlām/Hayāt recounts to Khālid that on the day Algeria gained its independence, she found her grandmother crying, and asked her why. She explains to Hayāt/Aḥlām that, in the past, she had looked forward to independence as the day when her son would be reunited with her, but that now she awaits nothing, for Ahlām/Hayāt's father died in the struggle for Algerian independence and would never be coming home. As Mustaghānamī writes: "the day my father died, my grandmother did not ululate as in the imaginary stories of the Revolution that I read later. She stood in the middle of the house, gasping with tears, shaking, her head uncovered, repeating with primal sadness." 57 The passage is followed by the grandmother's cries. On the next page, Hayāt/Aḥlām continues telling Khālid about her mother, grandmother and father, and Khālid asks: "Where do you know all these stories from?" 58 Ahlām/Hayāt responds: 'From her [her grandmother] ... and from my mother too," then continues to tell stories of local saints and names. ${ }^{59}$ Stories transmitted orally from one generation of Algerian women to the next here move from Ḥayāt/Aḥlām to Khālid, represented to an Arabic readership in modern standard Arabic. Though there is a register shift between the colloquial in which such a story would likely be recounted, and the standard Arabic shared by an audience of Arabic readers, the Arabic does not identify this moment in the novel as one particularly fraught within Algerias national linguistic history.

The French translation of this passage translates it mostly literally, changing only the grandmother's cries, such that this chain of Arabic storytelling seems to slide smoothly into French. The ease with which this passage of the novel can be translated from Arabic to French complicates Jacquemond's question-suggestion as to whether translators of Arabic to French might recycle strategies of Arab-Francophone writers. Assia Djebar's literary corpus, and in particular, her novel L'Amour, la fantasia (1985), addresses itself to the question of writing Algerian women's oral stories in a novel written in French, the

${ }^{57}$ Ibid., p. 107 "yawm māta abī lam tazgharad jiddati kamā fì qiṣaṣ al-thawra al-khayāliyya allati qara' tuha fīmā ba'd. Waqafat fĩ wusț al-dār wa-hiya tushhiq bi-l-bukā’ wa tantafiḍ 'āriyyat al-ra's muraddida bi-huzn bidā'î."

58 Ibid., p. 109 "min ayna ta rifiñna kull hādhahi-l-qișaș?"

59 Ibid. "minhā, hiya ... wa-min ummī ayḍan." 
only language in which Djebar is able to write. Indeed, she herself gave up writing in French upon Algeria's independence in 1962, not publishing a fictional work again until 1980, when her collection of short stories entitled Femmes d'Alger dans leur appartement came out. In the interim, critic Magda al-Nowaihi writes, "she apparently was attempting to move to writing in Arabic and failing to do so." ${ }^{60}$ L'Amour, la fantasia came out five years later in 1985. Throughout this autobiographical novel-cum-history, Djebar palimpsestically relies on the written accounts of the French colonizers and their entourage, and oral stories from Algerians to weave together a story of the French-Algerian wars. Writing in French, Djebar centrally stages in the novel the uneasy linguistic position she occupies. At one point she writes:

Après plus d'un siècle d'occupation française - qui finit, il y a peu, par un écharnement -, un territoire de langue subsiste entre deux peuples, entre deux mémoires; la langue française, corps et voix, s'installe en moi comme un orgueilleux préside, tandis que la langue maternelle, toute en oralité, en hardes dépenaillées, résiste et attaque, entre deux essoufflements. ${ }^{61}$

(After more than a century of French occupation-that ended, not long ago, with a flaying — a linguistic territory subsists between two peoples, between two memories; the French language, body and voice, has established itself in me like a proud one presiding, while the mother tongue, all orality, in tattered rags, resists and attacks, between two gasps.)

Earlier in the novel, there is a moment when Djebar recounts, in "the mother tongue," a story of two prostitutes, Fatma and Meriem, about whom she read in a book written in French by Fromentin. Gayatri Spivak writes that in this scene, "the tale shared in the mother tongue is forever present (in every act of reading) and forever absent, for it is in the mother tongue." ${ }^{62}$ This foreverpresent/forever-absent mother tongue is figured by Djebar as continually haunting her writing in L'Amour, la fantasia, a result of the linguistic territory of the French occupation of Algeria, divided for her between the proud French language and "the mother tongue, all orality, in tattered rags, [that] resists and attacks, between two gasps."

In an article engaging a number of North African Francophone texts, Samia Mehrez comments on Djebar's staging of this linguistic drama, and the effect such tensions in L'Amour, la fantasia have on the feasibility of its translation. Mehrez writes:

${ }^{60}$ Magda al-Nowaihi, "Resisting Silence in Arab Women's Autobiographies," International Journal of Middle East Studies 33 (2001), p. 488.

${ }_{61}$ Assia Djebar, L'Amour, la fantasia (Paris: Jean-Claude Lattès, 1985), p. 299.

${ }^{62}$ Gayatri Chakravorty Spivak, "Acting Bits/Identity Talk," Critical Inquiry 18, no. 4, Identities (Summer, 1992), p. 771. 
Any translation of this text into yet another language is bound to dissolve and mask these crucial confrontations.... As Djebar transcribes and translates, she creates a text that is at once a resister and liberator whose existence in French is undoubtedly the prime reason for its power and importance. ${ }^{63}$

L'Amour, la fantasia, like Dhäkirat al-jasad, is deeply marked by the language in which it is written, for Djebar is writing in a French that cannot but confront the tensions in the relationship between French and Arabic in her own life as in the history of Algeria's colonization. The discordance being measured in L'Amour, la fantasia is being measured from the perspective of a decolonizing Algerian French that, like Mustaghānamīs Arabic, is part of a national linguistic struggle.

It is this register of linguistic confrontation and tension that is missing in the facile French translation of the passage of Dhäkirat al-jasad in which Hayāt/ Ahlām recounts to Khālid stories her mother and grandmother have told her. It is precisely the issue of staging the Algerian national linguistic drama that confounds the novel's French translation as Mémoires de la chair. This translation of Dhäkirat al-jasad seems able only to omit, elide, stay silent on, or render unintelligible the original novel's investment in the politics of writing in Arabic in an Algerian context. The French translation and its reception by the French press tend to replace this linguistic drama with an appeal to Mustaghānamīss 'Algerian-ness.' The result is that the novel in French translation can neither be apprehended by its French readership as atomizing, pulverizing or haunting the linguistic history of the French language in an Algerian context, nor can it be manifestly legible as part of the larger Arabic literary tradition to which it claims allegiance.

${ }^{63}$ Samia Mehrez, "Translation and the Postcolonial Experience: the Francophone North African Text," Rethinking Translation: Discourse, Subjectivity, Ideology, Lawrence Venuti, ed. (New York: Routledge, 1992), p. 127. 